(C) 1989 ISIJ

/IIIIIIIIIIIIIIIII

寄 書

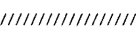

高速乱流酸洗液による熱間圧延鋼板の

高速酸洗の可能性

伊藤 雅彦* ・ 緑川平八郎 $*$. 木村 智明 $* 2$

山口 輝雄 $* 2$. 菊池 有二*2

\title{
Possibility of High Speed Pickling of Hot Rolled Strip by High Speed Turbulent Flow of Acid Solution
}

Masahiko ITOH, Heihachirō MidorIKAWA, Tomoaki KIMURA,

Teruo YAmaGUCHI and Yüji KIKUCHI

\section{1. 緒言}

熱間压延（以下，熱延と称す）鋼板のデスケーリング は後続の冷間压延（以下，冷延と称す）時のスケール巻 込みによる鋼板表面の損傷防止のために不叮欠であり， 通常は酸洗処理がおこなわれる，近年，冷延鋼板の生産 性向上のためにデスケーリングは程と冷延门程の連続化 が図られているが，これには前段のデスケーリングて程 の高速化が鍵となる.デスケーリングの高速化の一手段 として，最近ではスケールを機械的に破壊し，次いで塩 酸溶液に浸漬する方法が用いられている ${ }^{1)}$ 。このための 機械的なスケールブレーキング法が各所で検討 ${ }^{2)}$ れて いるが，酸洗自体の改良までには至っていない。そこで 本研究では, 鋼板と酸洗槽の間隙を狭くし, 酸液を乱流 状態で高速流動させることにより酸洗速度の问上(酸洗 時間短縮）を試みた。

\section{2. 高速乱流による高速酸洗の考え方}

熱延鋼板の塩酸酸洗において，スケールの溶解反応は 次のように表される3).

$$
\begin{aligned}
& \mathrm{Fe}_{2} \mathrm{O}_{3}+4 \mathrm{HCl} \longrightarrow 2 \mathrm{FeCl}_{2}+2 \mathrm{H}_{2} \mathrm{O}+1 / 2 \mathrm{O}_{2} \\
& \mathrm{Fe}_{3} \mathrm{O}_{4}+6 \mathrm{HCl} \longrightarrow 3 \mathrm{FeCl}_{2}+3 \mathrm{H}_{2} \mathrm{O}+1 / 2 \mathrm{O}_{2}
\end{aligned}
$$

酸洗速度を上げて酸洗時閏を短縮するには，上淤の溶解 反応を促進すれば良く，塩酸濃度及び温度が奇与するこ とが知られている。しかし，濃度及び温度は装置上ある いはコスト等の実用上の制約から無制限に高くはできな い. そこで実用的な範囲で酸洗速度を问上させるには拡 散の促進と鋼板温度を酸液温度まで急速に上昇させる必
要がある。すなわち，鋼极表而における物質移動（酸及 び伩応生成物の拡散）の促進と温度境界層の綰小による 熱伝達率の改善である。その手段として鋼极表再で酸液 を高速乱流化させて物質移動促進及び鋼极の急速昇温を 達成し酸洗時間の短縮を四る。

\section{3. 実 験 方 法}

\section{$3 \cdot 1$ 供試材}

供試材は板厚 $2.5 \mathrm{~mm}$, 板幅 $310 \mathrm{~mm}$ のコイル状の熱延 鋼板を用いた。 Table 1 にその化労組成を亦す。供試材 は熱延後 $800^{\circ} \mathrm{C}$ で巻き取ったもので，Fig. 1 にX線回 折結果を示すようにスケールは $\mathrm{Fe}_{3} \mathrm{O}_{4}$ が文成分であり， その他に $\mathrm{Fe}_{2} \mathrm{O}_{3}$ も若斗混在している。この供試材を消

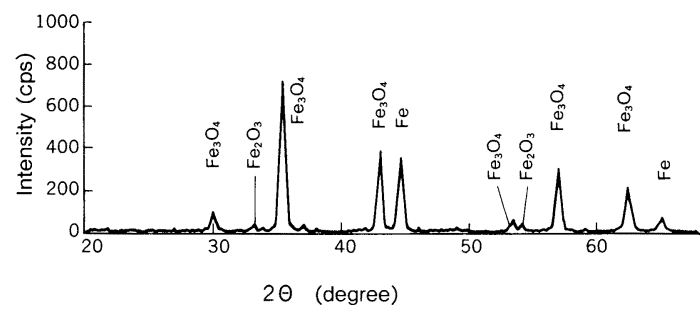

Coiling temperature $11973 \mathrm{~K}$

Fig. 1. X-ray diffraction pattern from surface of hot rolled strip.

Table 1. Chemical composition of steel (wt \%).

\begin{tabular}{cccccc}
\hline $\mathrm{C}$ & $\mathrm{Si}$ & $\mathrm{Mn}$ & $\mathrm{P}$ & $\mathrm{S}$ & $\mathrm{Fe}$ \\
\hline 0.01 & 0.01 & 0.12 & 0.015 & 0.017 & Bal.
\end{tabular}

昭和 60 年 10 月本会講演大会にて発表 平成元年 3 月 27 日受付 (Received Mar. 27, 1989)

*（株)日立製作所日立研究所 (Hitachi Research Laboratory, Hitachi, Ltd., 4026 Kuji-cho Hitachi 319-12)

*2（株）日立製作所日立l場（Hitachi Works, Hitachi, Ltd.)

Key words : carbon steel ; hot rolled strip ; acid pickling; scale ; turbulent flow. 


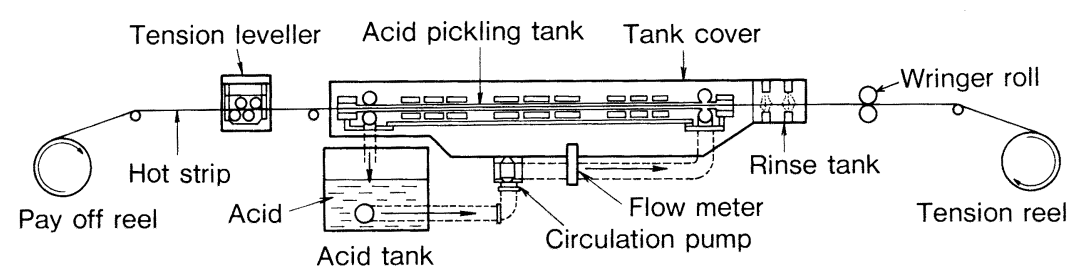

Fig. 2. Experimental apparatus for continuous pickling of hot rolled strip.

径 $50 \mathrm{~mm}$ のワークロールを 5 本備えたスケールブレー カーを通して柲の伸び譬が $5 \%$ になるように引張り曲げ 加厂をして前処理（スケールブレーキング）したものを 試験に用いた。

\section{$3 \cdot 2$ 実験装置}

実験装置の概略構成をFig. 2 に示す。本装㯰は酸液 の流動部と供試材の駆動部から構成されている. 酸洗槽 は全長 $3000 \mathrm{~mm}$, 供試材と酸洗槽の酸液が流れる間隙は $15 \mathrm{~mm}$ であり, 酸液はポンプによって供給され, 酸洗槽 と供試材の間隙を乱流状態で循環する構造となってい る. 本装㯰は酸洗槽部分で流速 $0 \sim 6 \mathrm{~m} / \mathrm{s}$, 通板速度 $0 \sim$ $40 \mathrm{~m} / \mathrm{s}$ の能力を存する.

\section{$3 \cdot 3$ 実験方法}

あらかじめ, 酸液タンク内で所起濃度の塩酸を実験温 度に加熱しておき，供武材を実験装置にセットし，テン ションリールを駆動して酸洗槽内を所分の速度で通板さ せながらポンプにより塩酸を循環させて酸洗した。その 後, 水洗して巻き取った. 酸洗の評価は試験後に $30 \times$ $30 \mathrm{~mm}$ の大きさの詊価用試験片を切りだしてインヒビ ターを添加した $5 \%$ 塩酸中に浸漬してスケールを全部溶 解し, 溶解前後の重量差から残存スケール量を求めた。 酸洗率は间じす法であらかじめ, 試験前のスケール量を 求めておき,これと試験後の残存スケール量の比から算 出した．鋼极温度の測定は試験材に淔径 $3 \mathrm{~mm}$, 深さ 0.5 $\mathrm{mm}$ の公をあけて，そこに熱電対の先端をはんだで埋め 込んで固定したものを用いた。

\section{4. 実験結果及び考察}

\section{$4 \cdot 1$ 流速の影響}

インヒビターとして $1 \%$ ヘキサチレンテトラアミン を添加した $70^{\circ} \mathrm{C} の 10 \%$ 塩酸水溶液を用い, 酸洗摔に 及ぼす流速の影響を調べた。その結果を Fig. 3 に示す。 供試材の予熱の有無にかかわらず酸液の流速が大きくな るに従って酸洗率が高くなる傾问を示した，スケールを 完全に除去するには予熱なし (常温)では流速が $2 \mathrm{~m} / \mathrm{s}$, 予熱あり $(323 \mathrm{~K})$ の場令は $1.5 \mathrm{~m} / \mathrm{s}$ である. 流速が大 きいほど,また，供試材温度が高いほど酸洗が促進され る. 次に $323 \mathrm{~K} に$ 予熱した供試材を用いてスケールを 完全に溶解するのに必要な酸洗時間に及ぼす流速の影響 について調べた結果を Fig. 4 に示す. 酸液の流動のな

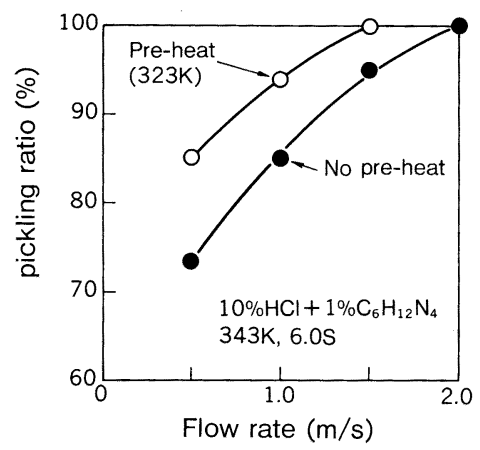

Fig. 3. Effect of flow rate on pickling ratio of hot rolled strip.

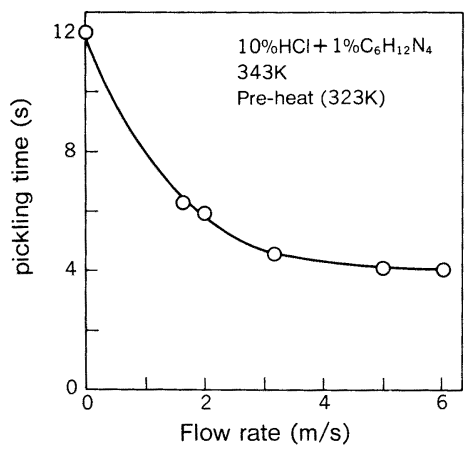

Fig. 4. Effect of flow rate on pickling time of hot rolled strip.

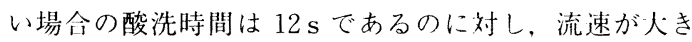
いほどその時間が短くなり流速 $5 \mathrm{~m} / \mathrm{s}$ では $4 \mathrm{~s}$ と酸洗時 間を 1/3 に短縮できる. Fig. 5 に, Fig. 4 の流速 $0 \mathrm{~m} / \mathrm{s}$ の酸洗時間に対する, 流速を与えた場命の酸洗時間の減 少の割合 $(\%)$ を酸洗時間短縮率として表した結果を示 す.酸洗時間短縮率は流速とともに大きくなり, 約 3 $\mathrm{m} / \mathrm{s}$ 以上でしだいに飽和する傾问を示した. $6 \mathrm{~m} / \mathrm{s}$ 以下 の乱流状態を熱延鋼板表面に付与することにより最大 $70 \%$ 程度の酸洗時間短縮率が得られた。

\section{$4 \cdot 2$ 温度の影響}

Fig. 6 に流速 $0 \mathrm{~m} / \mathrm{s}$ に扔ける酸洗時間と酸液温度の関 係を示す. 333〜 $353 \mathrm{~K}$ の温度範用ではスケールの完全 


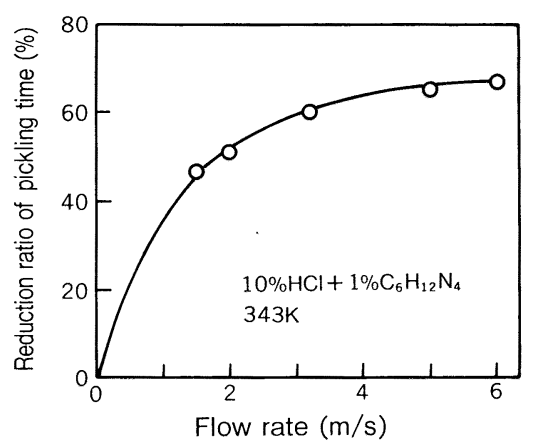

Fig. 5. Effect of flow rate on reduction ratio of pickling time of hot rolled strip.

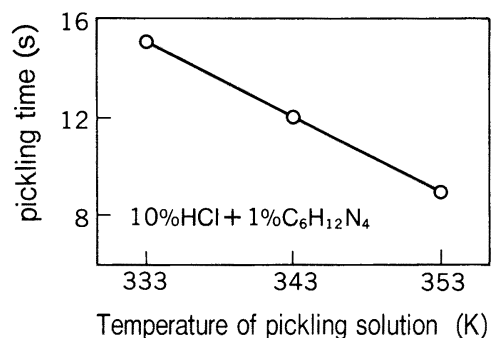

Fig. 6. Effect of temperature on pickling time of hot rolled strip.

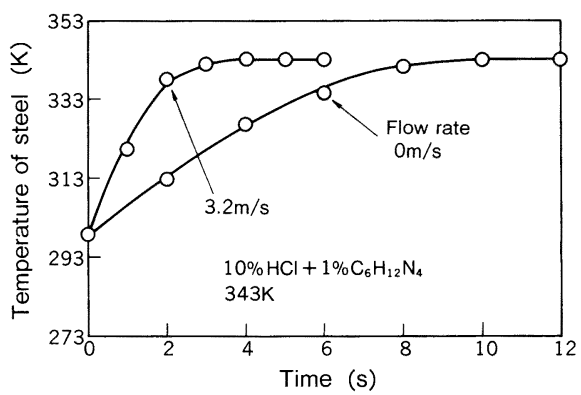

Fig. 7. Relation between dipping time, flow rate and steel temperature.

溶解に必要な酸洗時間は液温と直線関係があり, 液温が 高いほど短時間でスケールが溶解する．Fig. 7 に酸液中 の鋼板温度と浸漬時間の関係を示す.流速 $0 \mathrm{~m} / \mathrm{s}$ の場 合, 鋼板温度は塩酸溶液と同温度の $343 \mathrm{~K}$ に達するの には浸漬後 $10 \mathrm{~s}$ かかる.これに対して流速 $3.2 \mathrm{~m} / \mathrm{s}$ で は鋼板は $4 \mathrm{~s}$ で酸液の温度に達する. Fig. 6 と Fig. 7 から高速乱流による鋼板の急速昇温が酸洗時間短縮に寄 与していると考える.

\section{$4 \cdot 3$ 考察}

本報で用いた酸洗槽は，鋼板の幅力向の距離が鋼板と
酸洗槽の間隙に比べて十分に言い哀方形管路であること から酸液を円管内流体と似定して熱伝達及び物質移動を 考えてみる. 淔径 $d$ の管内で動粘性係数 レの流体が平 均流速 Uで流れる場令のレイノルズ数 Reは( 3 )式で 表される4).

$$
R e=U \cdot d / \nu
$$

一般に層流と乱流の境界である遷移 Re は $2000<R e$ $<4000$ と言われており, 本実験条件では（3)式より $0.5 \mathrm{~m} / \mathrm{s}$ 以上の流速では乱流となる.また, 定压比熱 $C_{p}$, 粘性係数 $\mu$, 熱伝導摔 $\lambda$ の流体のプラントル数 $\operatorname{Pr}$ は (4)式で示される.

$$
\operatorname{Pr}=C_{p} \cdot \mu / \lambda
$$

管内乱流熱伝達においてヌセルト数 $N u$ は ( 5 )式で, そ の時の管内熱伝達率 $h$ は $(6)$ 式でホされる.

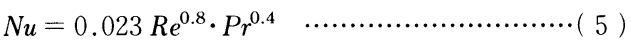

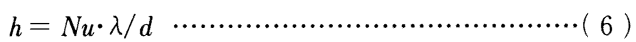

( 3 ) ～(6) 式より管内熱伝達率 $h$ は $(7)$ 式のようにな る.

$$
h=0.023(\lambda / d) \cdot(U \cdot d / \nu)^{0.8} \cdot\left(C_{p} \cdot \mu / \lambda\right)^{0.4}
$$

（７）式より熱伝達率は管径 $d$ が小さく流速 $U$ が大き いほど问上する。また，物質伝達率は（７)式の熱伝導率 $\lambda$ を拡散係数 $D$ に置き換えて求めることができ,この 場令も管径 $d$ が小さく流速 $U$ が大きいほど问上する. 本報では酸液流路を狭隙にし塩酸を高速乱流にしたこと で鋼板界面の熱伝達率の问上及び物質移動の促進が行わ れた結果，短時間で熱延鋼板のスケールを溶解すること ができたと考えられる。

\section{5. 結}

\section{言}

塩酸溶液中で熱延鋼板のスケールを短時間で溶解させ る高速酸洗の叮能性について検钶した。 その結果, 鋼板 と酸洗槽の間隙（酸液流路）を狭くして塩酸溶液を乱流 状態で流動させることにより従来のカテナリー方式に比 べて酸洗時間を大幅に短縮できる叮能性を得た。鋼板と 酸洗槽の間隙を $15 \mathrm{~mm}$ とした場令, 約 $3 \mathrm{~m} / \mathrm{s}$ 以上の流 速で酸洗時間を従来の約 $1 / 3$ に短縮することが可能で ある、これは高速乱流により鋼权/酸液界面での物質移 動及び熱伝達が促進されるためと推察した，高速酸洗装 置の実用化には，さらに最適流路形状や鋼板支持力法等 の検街が必要である。

\section{文献}

1 ) 秦和宣, 山以輝雄, 三本裕光, 菊池有二, 伊藤雅彦: Hi 評論, 67 (1985), p. 309

2 ) 伴 誠二, 明渡 博, 伊藤重晴, 佐野豊和: 第 34 回塑性 加工連合講演会了稿集 (1983), p. 269

3) H戸 元, 内藤浩光: H本金属学会会報, 16 (1977), p. 765

4 ) 伝熱丁学資料改訂第 3 版 (日本機械学会編) (1976), p. 28 [ H本機械学会] 